\title{
A study of descriptive data for orphans and non-orphans on key criteria of economic vulnerability in two municipalities in South Africa
}

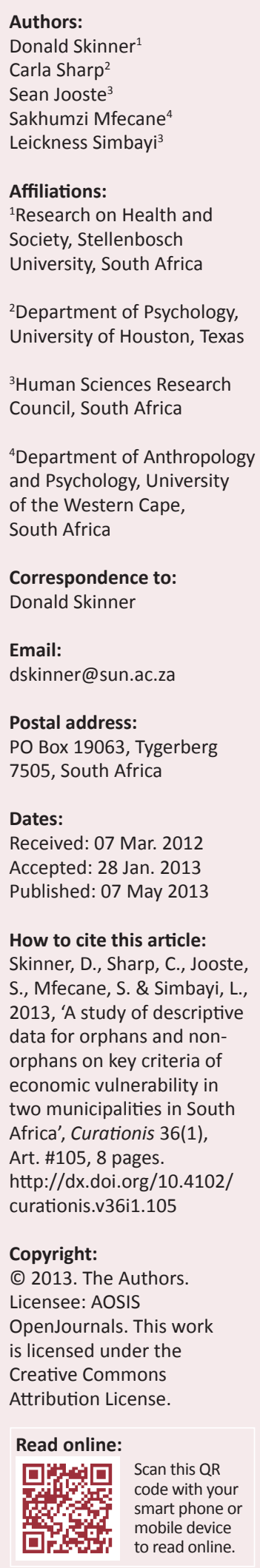

Authors:

Donald Skinner

Sakhumzi Mfecane

ckness Simbay

Society, Stellenbosch

${ }^{2}$ Department of Psychology,

${ }^{3}$ Human Sciences Research

and Psychology, University

of the Western Cape,

Correspondence to

Email:

dskinner@sun.ac.za

Postal address:

PO Box 19063, Tygerberg

Dates:

Received: 07 Mar. 2012

Accepted: 28 Jan. 2013

How to cite this article:

Skinner, D., Sharp, C., Jooste

S., Mfecane, S. \& Simbayi, L.

2013, 'A study of descriptive

or orphans and no

economic vulnerability in

two municipalities in Sout

Africa', Curationis 36(1)

Art. \#105, 8 pages.

http://dx.doi.org/10.4102/

is licensed under the

Creative Commons

Attribution License.

mart phone or

to read online.
Background: It is generally assumed that orphan status increases the risk to children of a range of negative outcomes. In South Africa, death of parents due to HIV-related illness is contributing to a rapid increase in the prevalence of orphans. This paper presents descriptive data from two South African communities, namely Kopanong, in the Free State and Kanana in the North West province, characterising the differences between orphans (double, maternal and paternal) and non-orphans on key criteria of social vulnerability.

Objectives: The objective was to obtain a better understanding of how different types of orphans and non-orphans may differ in these key areas as a crucial starting point for addressing the devastating consequences the AIDS epidemic has on these children's lives. While the study focuses on two specific areas these will provide insight into the general situation of orphans in South Africa.

Methods: A cross-sectional census survey was conducted in the two communities of Kopanong, comprising $n=5254$ households and Kanana, comprising $n=12984$ households.

Results: In Kopanong, 8.2\% of children had lost both parents, $19.1 \%$ had lost their father and $6.5 \%$ their mother only, whilst in Kanana the results were $6.5 \%, 28.1 \%$ and $3.7 \%$ respectively. Loss of both parents appeared to have a consistent impact on material need, including access to food, clothing and essential services, whilst loss of a single parent seems to have a more variable impact. At present, there are very few child headed households, but this constitutes a risk in the longer term.

Conclusions: Orphans appear to be more vulnerable in terms of material need. Children assessed in this study as being most in need were not accessing adequately many services directed at them. There is a need to extend understanding and measurement of emotional need and abuse.

\section{Introduction}

South Africa has one of the highest HIV-prevalence levels internationally, with reports in 2008 in a national seroprevalence survey of approximately $10.9 \%$ infected individuals in the two years and older age group, and 16.9\% for individuals of 15-49 years of age (Shisana et al. 2009). Annual antenatal surveys showed figures amongst pregnant women to be $29.1 \%$ in $2006,29.4 \%$ in 2007 and $29.3 \%$ in 2008 (Department of Health [DoH] 2009). The epidemic has serious implications both socially and economically, including an increase in the number of orphans. By the end of 2003, HIV-related deaths had given rise to about 1100000 orphans in South Africa (UNAIDS 2004). It is projected that if current risk practices do not change, about $15 \%$ of all children under the age of 15 years are expected to be orphaned in South Africa by 2015 (Johnson \& Dorrington 2001).

The premature death of parents due to HIV-related and other illness may impact on orphans in a variety of different ways. It certainly leads to significant changes in the household structure. Smart (2003) and Barnett and Whiteside (2002) discuss how HIV-related illness and death may lead to one or more generations of children being raised by their extended family or grandparents in households with very high dependency ratios, or to child headed-households. TheTV United Nations International Children's Emergency Fund - UNICEF (2003) established that southern African countries have a significantly-increased number of orphans living with female-headed households. About $40 \%$ of these children are being raised by grandparents (Berry \& Guthrie 2003).

For many children, the loss of parents is also associated with destitution, reduced access to schooling and stigmatisation by family and neighbours. For instance, children who have lost their parents to HIV-related illness may be at greater risk of malnutrition, illness and early school 
termination. Such results have already been recorded in households where HIV is diagnosed (Bachman \& Booysen 2006). The stigma and discrimination often associated with HIV may furthermore deprive orphans of basic social and education services. There is evidence that orphans may lose many basic material resources that caregivers usually provide (Whiteside 2000), or they may experience deepening debt and loss of their few assists because of the loss of a breadwinner (Donahue 2005). This situation can strain the traditional extended family and overwhelm already-stretched health and education systems in more severely-affected countries (Cluver \& Gardner 2007).

A qualitative report looking at the two communities covered in this paper (Skinner \& Davids 2005) shows orphans in South Africa to be more vulnerable than those in other countries. However, these assertions need to be demonstrated quantitatively. The first aim of the current paper is therefore to provide descriptive data for orphans and non-orphans on key criteria of economic vulnerability in two municipal areas in South Africa, namely Kopanong in the Free State, and Kanana in the North West province. Given the existing higher levels of poverty in these areas, even more so than in other areas of South Africa, one may well argue that all children there, regardless of orphan status, would be vulnerable to material need (Desmond \& Gow 2001; Hill \& Smith 2003).

Our second aim is to break down descriptive data for different types of orphans and to examine if any subtype (maternal, paternal or double orphan) might be more vulnerable in terms of not having access to basic resources such as food, clothing or adequate housing. Although very few empirical studies exist in this area, those that do, tend to provide data on orphaned versus non-orphaned status without acknowledging that findings may differ for different types of orphans.

These questions have particular relevance due to the high rates of HIV and poverty in the areas being researched. The HIV-prevalence levels found in a national seroprevalence study in 2004 were $10.9 \%$ for the North West Province and 12.6\% for the Free State. The respective prevalence for the 15-49 year age group, which is the age group that is most likely to have or be having children over the next 10 years was 18\% in the North West Province and $19.2 \%$ in the Free State at the time of the surveys (Shisana et al. 2005). Prevalence amongst women in public antenatal care in 2006 was found to be $30.0 \%$ (confidence interval 27.0-31.1) in the North West Province and $30.1 \%$ (confidence interval 29.2-33.1) in the Free State in 2006 (DoH 2009).

Given the high rate of HIV-related illness in these areas, high numbers of orphans are not surprising. Indeed, the 2001 census showed that in Kopanong, 480 children (2.1\%) of 18 years and younger had lost both parents, $1344(6 \%)$ had lost their mothers and $2762(12.3 \%)$ had lost their fathers. Applying this to the under-6 age group, $37(0.6 \%)$ had lost both parents, $136(2.1 \%)$ had lost only their mothers and 375
(5.9\%) had lost their fathers (Stats SA 2001). In Kanana, 1304 children (5.4\%) under 18 years of age had lost their mothers and 3206 (3.2\%) had lost their fathers (Stats SA 2001).

A better understanding of how diverse types of orphans and non-orphans may differ in these (and other) areas is a crucial starting point for addressing the devastating consequences that the HIV epidemic has had on these children's lives. Knowing whom to target first is essential in addressing the enormous need faced by communities.

\section{Problem statement}

It is generally assumed that orphan status in children increases the risk of a range of negative outcomes. Clarity is needed as to what these negative outcomes are, so that policy can be established and planning done to protect these orphaned children.

\section{Research objectives}

This paper, using a case study of two South African communities, aims to understand the economic impact on families and, in turn, on those children who have lost either one or both parents.

The specific objectives are to compare households that include children that are orphaned with households where no children are orphaned, on the basis of a range of economic indicators including access to income, food and services, as well as ownership of key household assets.

\section{Definition of concepts}

For this paper, an orphan is described as a child who has lost either of his or her parents. The parent could be lost to death or could have disappeared and his or her status is unknown. The definition of an orphaned and vulnerable child includes both the above definition of an orphan and any child who is felt to be compromised due to any other threat or difficult circumstances including poverty, abuse, lack of attention, lack of access to services for health or education amongst others (Skinner et al. 2006).

Key household assets are items that indicate a level of access to financial resources in the household and are important for survival or for ease of living. Examples include a stove, fridge, telephone, television (TV) and car.

\section{Contribution to field}

Considerable debate remains around the situation and needs of orphaned children, especially in the context of the HIV epidemic, where the number of orphaned children has increased considerably. The epidemic has also placed increasing pressure on entire communities. This paper adds to current understanding by providing insights into the situation of children orphaned in two poor communities in different parts of South Africa. 


\section{Research methods and design Design}

The specific design that is reported on here is of a crosssectional census survey, done as part of a larger study on orphaned and vulnerable children.

\section{Methods}

\section{Participants}

This research forms part of a much larger study aimed at informing the development of interventions with orphaned and vulnerable children (OVC) across 17 research sites in Botswana, South Africa and Zimbabwe. The full study has multiple objectives, with the key aim being the development, implementation and evaluation of best-practice interventions for OVC as well as their households and communities, to act as models for other sites in Africa and further afield (Skinner et al. 2006). Ethical approval for the entire study was obtained prior to data collection. The aim of the census survey was to obtain descriptive data in these specific communities for later research and intervention development (Jooste, Managa \& Simbayi 2006).

\section{Context of the study}

Census surveys were carried out in the two communities of Kopanong in the southern Free State and Kanana in the North West Province of South Africa. A fuller description of the census survey can be obtained from the original published report (Jooste et al. 2006). Community entry was carefully negotiated by the researchers with both formal gatekeepers and other key individuals and stakeholders in both communities. Some qualitative research and a situation analysis had been conducted previously, so many community members were familiar with the study when the survey took place.

Participant characteristics are summarised in Table 1. The entire population including all households $(n=18$ 238) amongst the previously-disadvantaged communities found in the nine small towns in Kopanong Municipality $(n=5254)$ and Kanana township ( $n=12984)$, served as participants in the census. Whilst this included all residents of Kanana, those living on farms and in the wealthier areas of the towns in Kopanong were excluded, largely on practical grounds.

Kanana Township is part of the City Council of Klerksdorp, a major gold mining area of the North West province. Historically, the community was an apartheid-defined township and still remains almost exclusively African. A

TABLE 1: Summary of participant characteristics for Kopanong and Kanana

\begin{tabular}{lll}
\hline Variables & Kopanong & Kanana \\
\hline No. of households & 5225 & 12984 \\
Total respondents & 21515 & 50984 \\
Average people per household & 4.12 & 3.93 \\
Mean age & 27.2 & 25.6 \\
Population under 18 & $45 \%$ & $40.10 \%$ \\
Population under 5 & $18.30 \%$ & $10.40 \%$ \\
\hline Percentage of women & $56 \%$ & $53 \%$ \\
\hline
\end{tabular}

Source: Data collected during the study variety of housing structures exist in Kanana, ranging from informal settlements and migrant workers' hostels that have recently been transformed into families dwelling units, to both old and new formal houses. The informal settlements in Kanana share communal taps and bucket toilets. The road infrastructure in Kanana is mostly underdeveloped, particularly in and around the informal settlements.

At the time of the survey, Kanana had nine primary schools, one intermediate school and four secondary schools, which were distributed throughout the township. There are two clinics in Kanana. The unemployment rate in the southern district of Klerksdorp stood at $40.1 \%$ in $2002 / 2003$ and was increasing (Stats SA 2001). The level of poverty is also very high with the reported level of unemployment in the broader area being reported as being 40.1\% in 2002/2003 (City Council of Klerksdorp 2003). Community members described the levels of crime as being very high, with robbery being the most common type of crime. High alcohol use was also reported (Skinner \& Davids 2006).

At the time of the survey, $16 \%$ of the population received government support grants. Of these grants $24.2 \%$ were pensions, $63.5 \%$ child grants, $9.1 \%$ disability grants, $1.9 \%$ foster grants and $1.3 \%$ unemployment support. Women constituted $40.7 \%$ of all household heads, and $0.2 \%$ of household heads were 14-18 years of age.

Kopanong Municipality is a subdistrict in the Free State province, consisting of nine towns. It is predominantly rural, with many farms and a number of small farming towns. These towns are distributed over the extensive diamondshaped municipality, which measures about $200 \mathrm{~km}$ from north to south and $180 \mathrm{~km}$ from east to west. The population of Kopanong in 2001 included 72.5\% African, 17.8\% Coloured and $9.6 \%$ White people (Stats SA 2001). The age distribution was biased toward the young: $33.96 \%$ were children $(<18$ years) and $34.35 \%$ were young adults (18-39), followed by $27 \%$ middle-aged (40-64) and $6.71 \%$ elderly (>64) people (Stats SA 2001).

Transport was difficult given the size of the community. For those towns situated near national roads, particularly the national highway that skirts along the edge of the area, the roads were tarred and well maintained, but within the district, there were mainly gravel roads linking one town to another. Public transportation was undeveloped as a result of the distances and small population of the towns. The main mode of transport was 16-seater taxis.

Housing arrangements reflected the national trend, wherein Whites predominantly occupy wealthier suburbs and African and Coloured people mainly dominate separate townships. Most township dwellers resided in formal houses, but some lived in shacks. Clean water was available to $91 \%$ of residents of the Xhariep district (Xhariep Integrated Development Plan [IDP] 2003). The Human Sciences Research Council (HSRC) census (Skinner \& Davids 2006) of the community found the population to be 40906 , with $52 \%$ being females. Only about $23 \%$ of people of working age were gainfully employed. 
About $10 \%$ of households reported no income, whilst $13 \%$ lived below the poverty line at the time (i.e. R635 per month - less than \$100).

The economy of the district was dependent primarily on agriculture, followed by government services and, to a lesser extent, mining (Xhariep IDP 2003). The dependence on agriculture meant that the economy of the district was at risk, due to the decline of the agricultural sector over the previous few years and frequent droughts. Informal trade, such as establishing home-based shops selling household items or cool drinks - a standard back-up source of income for the unemployed - did not exist in these towns. The small economic base of the communities meant that there were no big mainstream supermarkets, which had travel cost implications (Xhariep IDP 2003).

\section{Data collection methods}

Measures: A two-page census record sheet was used to obtain information about all occupants in the household. Questions covered the following areas: household structure; including number of people in each household; their age; gender; position in household; orphan status; having a birth certificate; education levels; and individual access to food. Household information was collected on access to services; nature of housing; socio-economic status indicators such as income; equipment in the household; access to water and the nature of the ablution facilities. Finally, there was a set of questions on factors that could increase child vulnerability.

Procedures: The heads of each household were approached for interviews by teams of enumerators led by supervisors who conducted the census in the two sites. Informed consent was obtained before continuing with the interview. Fieldwork was conducted in November 2003 in Kopanong, and in April 2004 - May 2004 in Kanana. In cases where no one was home or where no one was qualified to complete the questionnaire, fieldworkers returned to the households, for a maximum of two visits. Fieldwork lasted for two to three weeks in each community using teams of around 60 fieldworkers deployed in each community.

Teams met at the end of each day and each questionnaire was checked by the fieldworker who administered the questionnaire and by the supervisors. Completed questionnaires were handed to project coordinators in the field. The coordinators remained in the field for the entire duration of the project and carried out the final quality checks.

\section{Data management and analyses}

The data were double-entry captured and analysed using SPSS 20. Most of the analyses were carried out using frequency distributions and chi-square analyses. To determine group differences, standardised residuals were used. Cell residuals larger than \pm 2 indicate the difference between the 'observed $\%$ ' and 'expected \%' cell in the chi-square analyses and thus assist in indicating which group percentage accounts for a significant chi-square result.

\section{Results}

The descriptive data of the orphaned status in the two communities is presented below according to variables of potential economic vulnerability.

\section{Orphaned status}

Table 2 shows that in Kopanong, $8 \%$ of children had lost both parents, $19 \%$ had lost their father and 6.5\% their mother only, whilst in Kanana, the results were $6.5 \%, 28 \%$ and $4 \%$ respectively. As shown in Tables 3 (Kanana) and 4 (Kopanong), there were no differences in gender representation across orphan status in that there were approximately equal numbers of boys and girls across all categories.

\section{Key indices of vulnerability}

Percentages for each category of orphan status and chi-square $p$-values for indices of vulnerability are summarised in Tables 3 and 4 .

\section{Birth certificates}

Lack of birth certificates increases vulnerability as these are essential for obtaining financial grants from the government and accessing other services. Most children in Kanana had a birth certificate (92\%). There were significant differences between groups regarding birth certificate. An investigation of standardised residuals revealed that the difference accounting for the overall significant chi-square could be accounted for by the maternal orphan group. Compared with other groups, maternal orphans showed a higher number of children without a birth certificate.

Overall, fewer children in Kopanong had a birth certificate $(78 \%)$. As in Kanana, there were significant differences between groups. Maternal, paternal and double orphans were significantly more likely to not have a birth certificate than children with both parents, with the largest standardised residual associated with double orphan status.

\section{Access to food}

In Kanana, $41 \%$ of all children received 1-2 meals per day and $51 \%$ of children were reported to go without food for one day a week. There were significant group differences with regard to access to food. Investigation of the standardised residuals revealed that both paternal orphans and double orphans were significantly more likely to have limited access to food with double orphans being most vulnerable with regard to meals per day and going without food for one day per week.

TABLE 2: Status of parents of children in the communities.

\begin{tabular}{lccccc}
\hline Status of parents & \multicolumn{2}{c}{ Kopanong } & & \multicolumn{2}{c}{ Kanana } \\
\cline { 2 - 3 } \cline { 6 - 6 } & $\boldsymbol{n}$ & $\mathbf{\%}$ & & $\boldsymbol{n}$ & $\mathbf{\%}$ \\
\hline Both parents alive, present & 5273 & 66.5 & & 12217 & 61.7 \\
Lost mother & 518 & 6.5 & & 739 & 3.7 \\
Lost father & 1499 & 18.9 & & 5556 & 28.1 \\
Lost both parents & 632 & 8.0 & & 1277 & 6.5 \\
\hline Total & $\mathbf{7 9 2 2}$ & - & & $\mathbf{1 9 7 8 9}$ & - \\
\hline Source: Data collected during the study & & & &
\end{tabular}

$n$, Given as number. 
TABLE 3: Difference between non-orphans, maternal, paternal and double orphans on key criteria of vulnerability in Kanana, Botswana.

\begin{tabular}{|c|c|c|c|c|c|c|c|}
\hline \multirow[t]{2}{*}{ Variables } & \multirow[t]{2}{*}{ Criterion } & \multirow[t]{2}{*}{ Total (\%) } & \multirow[t]{2}{*}{ Non-orphans (\%) } & \multicolumn{3}{|c|}{ Orphans (\%) } & \multirow[t]{2}{*}{$p$-value } \\
\hline & & & & Maternal & Paternal & Double & \\
\hline \multirow[t]{2}{*}{ Gender } & Male & 49.8 & 49.9 & 51.0 & 49.4 & 49.7 & ns \\
\hline & Female & 50.2 & 50.1 & 49.0 & 50.6 & 50.3 & \\
\hline & No & 8.1 & 7.7 & $11.5^{\mathrm{a}}$ & 8.2 & 9.2 & \\
\hline \multirow[t]{2}{*}{ Meals per day } & $1-2$ meals & 40.6 & $37.0^{\mathrm{a}}$ & 42.5 & $46.7^{\mathrm{a}}$ & $47.4^{\mathrm{a}}$ & $<0.001$ \\
\hline & 3-4 meals & 59.4 & $63.0^{\mathrm{a}}$ & 57.5 & $53.3^{\mathrm{a}}$ & $52.6^{\mathrm{a}}$ & \\
\hline \multirow[t]{2}{*}{ Day without food } & Yes & 51.0 & $45.9^{\mathrm{a}}$ & 52.1 & $59.8^{\mathrm{a}}$ & $61.7^{\mathrm{a}}$ & $<0.001$ \\
\hline & No & 49.0 & $54.1^{\mathrm{a}}$ & 47.9 & $40.2^{\mathrm{a}}$ & $38.3^{\mathrm{a}}$ & \\
\hline \multirow[t]{2}{*}{ School attendance } & Yes & 93.9 & 94.9 & 92.9 & 93.2 & 89.9 & $<0.001$ \\
\hline & No & 6.1 & 5.1 & 7.1 & 6.8 & $10.1^{\mathrm{a}}$ & \\
\hline \multirow[t]{2}{*}{ Toilet facilities } & Flush & 56.5 & $57.9^{\mathrm{a}}$ & $62.4^{\mathrm{a}}$ & $52.8^{\mathrm{a}}$ & 55.2 & $<0.001$ \\
\hline & Other & 43.5 & $43.5^{\mathrm{a}}$ & 42.1 & $37.6^{\mathrm{a}}$ & 47.2 & \\
\hline \multirow[t]{2}{*}{ Access to water } & Premises & 73.5 & 73.3 & 77.5 & 72.5 & 77.1 & $<0.001$ \\
\hline & $>500 \mathrm{~m}$ & 26.5 & 26.7 & $22.5^{\mathrm{a}}$ & 27.5 & $22.9^{\mathrm{a}}$ & \\
\hline Electricity cooking & Yes & 31.6 & $35.6^{\mathrm{a}}$ & 32.3 & $23.0^{\mathrm{a}}$ & 30.6 & $<0.001$ \\
\hline \multirow[t]{2}{*}{ Electricity lighting } & Yes & 89.4 & 90.1 & 91.0 & 87.5 & 89.6 & $<0.001$ \\
\hline & No & 10.6 & $9.9^{\mathrm{a}}$ & 9.0 & $12.5^{\mathrm{a}}$ & 10.4 & \\
\hline \multirow[t]{2}{*}{ Television } & Yes & 58.4 & $62.3^{\mathrm{a}}$ & 58.5 & $49.8^{\mathrm{a}}$ & 59.5 & $<0.001$ \\
\hline & No & 41.6 & $37.7^{\mathrm{a}}$ & 41.5 & $50.2^{\mathrm{a}}$ & 40.5 & \\
\hline \multirow[t]{2}{*}{ Radio } & Yes & 64.9 & $68.3^{\mathrm{a}}$ & 67.9 & $57.2^{\mathrm{a}}$ & 63.2 & $<0.001$ \\
\hline & No & 35.1 & $31.7^{\mathrm{a}}$ & 32.1 & $42.8^{a}$ & 36.8 & \\
\hline \multirow[t]{2}{*}{ Phone } & Yes & 26.1 & $29.9^{a}$ & 23.7 & $19.3^{\mathrm{a}}$ & $21.1^{\mathrm{a}}$ & $<0.001$ \\
\hline & No & 73.9 & $70.1^{\mathrm{a}}$ & 76.3 & $80.7^{\mathrm{a}}$ & 78.9 & \\
\hline \multirow[t]{2}{*}{ Car } & Yes & 7.1 & $9.5^{\mathrm{a}}$ & 6.9 & $2.3^{\mathrm{a}}$ & $5.1^{\mathrm{a}}$ & $<0.001$ \\
\hline & No & 92.9 & $90.5^{\mathrm{a}}$ & 93.1 & $97.7^{\mathrm{a}}$ & 94.9 & \\
\hline \multirow[t]{2}{*}{ Access to clothing } & Yes & 40.1 & $45.1^{\mathrm{a}}$ & 39.5 & $32.0^{\mathrm{a}}$ & $28.5^{\mathrm{a}}$ & $<0.001$ \\
\hline & No & 59.9 & $54.9^{\mathrm{a}}$ & 60.5 & $68.0^{\mathrm{a}}$ & $71.5^{a}$ & \\
\hline \multirow[t]{2}{*}{ Access to medical } & Yes & 69.7 & 71.8 & 70.5 & $65.9^{a}$ & 65.4 & $<0.001$ \\
\hline & No & 30.3 & $28.2^{\mathrm{a}}$ & 29.5 & $34.1^{\mathrm{a}}$ & $34.6^{\mathrm{a}}$ & \\
\hline
\end{tabular}

ns, not stated.

Total households were 12984 . Cell counts and Chi-square values can be obtained directly from the second author (C.S.).

a, Percentages are standardised cell residuals larger than \pm 2 . Cell residuals indicate the difference between the observed percentage and expected percentage cell in the chi-square analyses and assist in indicating which group percentage accounts for a significant $p$-value result.

TABLE 4: Difference between non-orphans, maternal, paternal and double orphans on key criteria of vulnerability in Kopanong.

\begin{tabular}{|c|c|c|c|c|c|c|c|}
\hline Variables & Criterion & Total & Non-orphans (\%) & Maternal (\%) & Paternal (\%) & Double (\%) & $p$-value \\
\hline \multirow[t]{2}{*}{ Gender } & Male & 48.2 & 48.5 & 48.8 & 47.4 & 47.3 & ns \\
\hline & Female & 51.8 & 51.5 & 51.2 & 52.6 & 52.7 & \\
\hline \multirow[t]{2}{*}{ Birth certificate } & Yes & 84.0 & 86.4 & 78.2 & 80.5 & 77.3 & $<0.001$ \\
\hline & No & 16.0 & $13.6^{\mathrm{a}}$ & $21.6^{\mathrm{a}}$ & $19.5^{\mathrm{a}}$ & $22.7^{\mathrm{a}}$ & \\
\hline \multirow[t]{2}{*}{ Meals per day } & $1-2$ meals & 22.4 & $20.7^{a}$ & 22.9 & $26.5^{\mathrm{a}}$ & 24.8 & $<0.001$ \\
\hline & 3-4 meals & 77.6 & 79.3 & 77.1 & $73.5^{\mathrm{a}}$ & 75.2 & \\
\hline \multirow[t]{2}{*}{ Day without food } & Yes & 44.7 & $43.1^{\mathrm{a}}$ & $36.2^{\mathrm{a}}$ & $51^{a}$ & 48.7 & $<0.001$ \\
\hline & No & 55.3 & 56.9 & $63.8^{\mathrm{a}}$ & $49.0^{\mathrm{a}}$ & 51.3 & \\
\hline \multirow[t]{2}{*}{ School attendance } & Yes & 94.2 & 94.2 & 92.5 & 95.4 & 93.6 & ns \\
\hline & No & 5.8 & 5.8 & 7.5 & 4.6 & 6.4 & \\
\hline \multirow[t]{2}{*}{ Toilet facilities } & Flush & 88.4 & 87.1 & 92.2 & 90.0 & 90.6 & $<0.001$ \\
\hline & Other & 11.6 & $12.9^{\mathrm{a}}$ & $7.8^{\mathrm{a}}$ & $10.0^{\mathrm{a}}$ & $9.4^{a}$ & \\
\hline \multirow[t]{2}{*}{ Access to water } & Premises & 84.8 & 83.2 & 82.6 & $90.3^{a}$ & 86.1 & $<0.001$ \\
\hline & $>500 \mathrm{~m}$ & 15.2 & $16.8^{\mathrm{a}}$ & 17.4 & $9.7^{a}$ & 13.9 & \\
\hline \multirow[t]{2}{*}{ Electricity - cooking } & Yes & 34.5 & 35.7 & 31.5 & 33.0 & 30.8 & ns \\
\hline & No & 65.5 & 64.3 & 68.5 & 67 & 69.2 & \\
\hline \multirow[t]{2}{*}{ Electricity - lighting } & Yes & 87.2 & 86.2 & 88.7 & 88.9 & 89.5 & 0.001 \\
\hline & No & 12.8 & $13.8^{\mathrm{a}}$ & 11.3 & $11.1^{\mathrm{a}}$ & 10.5 & \\
\hline \multirow[t]{2}{*}{ Television } & Yes & 50.7 & 51.4 & 50.9 & 49.1 & 48.8 & ns \\
\hline & No & 49.3 & 48.6 & 49.1 & 50.9 & 51.2 & \\
\hline \multirow[t]{2}{*}{ Radio } & Yes & 65.7 & 66.7 & 64.9 & 63.7 & 63.4 & ns \\
\hline & No & 34.3 & 33.3 & 35.1 & 36.3 & 36.6 & \\
\hline \multirow[t]{2}{*}{ Phone } & Yes & 18.7 & 18.9 & 20.9 & $15.8^{\mathrm{a}}$ & $22.4^{\mathrm{a}}$ & $<0.001$ \\
\hline & No & 81.3 & 81.1 & 79.1 & 84.2 & 77.6 & \\
\hline \multirow[t]{2}{*}{ Car } & Yes & 7.0 & $8.3^{\mathrm{a}}$ & 6.9 & $3.7^{\mathrm{a}}$ & $5.2^{\mathrm{a}}$ & $<0.001$ \\
\hline & No & 93.0 & 91.7 & 93.1 & 96.3 & 94.8 & \\
\hline \multirow[t]{2}{*}{ Adequate clothing } & Yes & 61.1 & 62.8 & 61.3 & $57.3^{\mathrm{a}}$ & 56.7 & $<0.001$ \\
\hline & No & 38.9 & $37.2^{\mathrm{a}}$ & 38.7 & $42.7^{a}$ & $43.3^{\mathrm{a}}$ & \\
\hline \multirow[t]{2}{*}{ Medical services } & Yes & 74.5 & 75.1 & 74.8 & 76.9 & $65.0^{\mathrm{a}}$ & $<0.001$ \\
\hline & No & 25.5 & 24.9 & 25.2 & $23.1^{\mathrm{a}}$ & $35.0^{\mathrm{a}}$ & \\
\hline
\end{tabular}

ns, not stated.

a Percentages are standardised cell residuals larger than \pm 2 . Cell residuals indicate the difference between the observed $\%$ and expected $\%$ cell in the chi-square analyses and assist in indicating which group percentage accounts for a significant chi-square result. 
In Kopanong, 22\% of children had 1-2 meals per day and $43 \%$ of children went without food for one day a week. As for the relationship between access to food and orphan status, the values of standardised residuals again revealed that nonorphans were significantly more likely to have access to 3-4 meals a day and to be less likely to go without food for one day a week. No differences were found for maternal or double orphans in the number of meals per day, whilst paternal orphans were significantly more likely to have only 1-2 meals per day. Paternal orphans were also significantly more likely go without food for a day, along with double orphans.

\section{School attendance}

School attendance was very high in both communities. In Kanana, 94\% of children were attending school but with some variation across the groups. Chi-square tests revealed that double orphans were least likely to attend school, while non-orphans were most likely to attend school. In Kopanong, school attendance was very high across all the groups (94\%), with no significant differences across groups.

\section{Flush toilets}

Fifty-six per cent of children in Kanana had a flush toilet at home, whilst the rest used a bucket or a pit latrine. Maternal orphans were most likely to have access to flush toilets. In Kopanong $88 \%$ of children lived in a dwelling with a flush toilet. As with Kanana, maternal orphans were most likely to have access to flush toilets, followed by double and then paternal orphans.

\section{Access to water}

Seventy-three per cent of children in Kanana had access to water on their premises. Differences between groups were negligible. Eighty-five per cent of children in Kopanong had access to water on the premises, but paternal orphans were least likely to have access to water.

\section{Access to electricity}

Only 32\% of the households of Kanana had access to electricity for cooking, with most households (66\%) using paraffin. Eighty-nine per cent of households had access to electricity for lighting. In both cases chi-square analyses showed significant differences between non-orphans and orphans, with paternal orphans being the most disadvantaged.

Only $34 \%$ of the households of Kopanong had access to electricity for cooking, with most households (58\%) using paraffin; $87 \%$ had electricity for lighting. Differences between groups were generally small.

\section{Household equipment}

In Kanana, 59\% of households owned a TV, $65 \%$ owned a radio, $26 \%$ owned a phone and $7 \%$ owned a car. Across all household appliances, the same pattern of results emerged with nonorphans being significantly more likely to have appliances, and paternal orphans being significantly less likely.
In Kopanong, $51 \%$ of households owned a TV, $66 \%$ owned a radio, $19 \%$ owned a phone and $7 \%$ owned a car. No significant differences at between orphan status groups were found with regard for ownership.

\section{Access to clothing and school uniforms}

Forty per cent of children in Kanana had adequate clothing. Non-orphans were significantly more likely than other groups to be adequately clothed with double and paternal orphans significantly worse off in this regard. Sixty-one per cent of children in Kopanong had adequate clothing at time of the census. Again, paternal and double orphans were significantly more likely to be inadequately clothed.

\section{Access to medical services}

Seventy per cent of children in Kanana had access to medical services. Chi-square analyses showed significant differences between groups, with non-orphans having most access to medical services and paternal and double orphans more likely to have limited access.

Seventy-five per cent of children in Kopanong had access to medical services. Chi-square analyses showed significant differences between groups with double orphans most likely to have limited access.

\section{Ethical considerations}

Ethical approval was obtained for the study prior to entering the field. All respondents signed a letter of informed consent. There was no pressure put on households to participate, and there were also no direct benefits or hazards that would have arisen from the research. Data were collected anonymously with no personal identification being attached to any questionnaire. All data was held on passwordprotected computers.

\section{Trustworthiness}

The census data could be considered a reliable and valid representation of the context of the communities at the time of the research, as there are no indicated biases in the research process and no vested interests in tampering with the results. The research instrument had been piloted previously and was found to be both easily understandable and to collect the information accurately.

\section{Discussion}

The aim of the current article was to investigate whether orphan status poses additional risk in terms of key indices of economic vulnerability. When considering the sample as a whole, the data presented here clearly suggest that all children in Kanana in the North West and Kopanong in the Free State, South Africa are at great risk due to significant poverty in the region, regardless of orphan status. About half of the children in both communities go at least one day a week without food and relatively few households have electricity for cooking. Too few children have adequate clothing and too 
many have limited access to medical services. Given the high unemployment levels in these areas and the low potential for economic growth, it was unlikely that additional resources would be made available for children.

Given the significant poverty in these regions, it is therefore alarming that our data suggest that orphan status poses additional risk for children. It appears that double and paternal orphans are most vulnerable in terms of the key indices of economic vulnerability. The loss of fathers has a significant impact, as it is associated with a loss of income and access to resources. Fathers can be absent due to death mostly from HIV-related illness or violence, or by desertion due to his returning home after completing a contract or by simply ending the relationship and contact with the mother.

This is part of the largest study yet conducted in South Africa to investigate the impact of orphan status on households in terms of key indices of economic vulnerability. There are some limitations to this study that warrant discussion. Most notably, in Kopanong data were not collected in the wealthier areas or on farms (where conditions are thought to be considerably worse). The impact of these omissions is difficult to ascertain.

Our findings clearly suggest that the loss of a father has the greatest economic impact on children. This does not imply that loss of a mother is negligible, but it suggests that loss of a mother plays a greater role in the non-economic domain. Indeed, a qualitative study suggested that loss of mothers represented more a loss of caring (Skinner \& Davids 2005). An important next step would be to include measurements of emotional care and support in future research. The impact of the loss of mothers is important to look at urgently, given the high prevalence of HIV amongst antenatal clinic attendees in the provinces concerned (DoH 2009).

In addition, whilst our study focuses on the impact of the loss of parents on economic vulnerability, research on the impact of orphan hood on mental health is warranted. So far, mixed results have been found in this regard. In a small study in the Eastern Cape comparing children with both parents and those children orphaned by HIV and/or other reasons, Wild et al. (2005) showed no negative impact to being orphaned by HIV-related illness. In this case, however, children orphaned by HIV-related illness were receiving additional beneficial treatment. Using similar groups, Cluver and Gardner (2007) found distinct variations, with those children who had been orphaned by HIV-related illness being significantly more likely to be depressed, have social problems and demonstrate post-traumatic stress symptoms.

\section{Limitations of the study}

The major limitation of the study is that, being a crosssectional study, changes in the variables cannot be seen over time, so it cannot be shown directly that orphan status has any bearing on the reduction in economic status. This was assumed from the data.

\section{Conclusions}

Children in these two communities were shown to be experiencing a number of economic hardships. Poverty is an important risk factor already impacting on crucial factors, such as having an adequate living space, regular food, and sufficient clothing, amongst others. Being orphaned, especially having lost a father as either a paternal orphan or a double orphan, resulted in significantly-worse living conditions than other children in the community. This indicates that fathers remain the major source of income for most households, meaning that when they are missing the family does suffer considerably.

\section{Recommendations}

Our study points to the need to separate orphans into subtypes of maternal, paternal and double orphans for future work, whether investigating economic vulnerabilities or mental health. Long term follow-up is also required on impacts such as health, malnutrition, growth, mental health, educational achievements and personality development. Our data shows that the prevalence of orphanhood is very high in both Kanana and Kopanong. Given the additional risk that especially paternal and double orphan status poses in terms of key indices of economic vulnerability, and potentially in other forms of vulnerability such as mental health, it is very important that parents gain adequate access to anti-retroviral medication (ARVs), and to provide subsistence support for families so that they can access adequate healthy food. Given that a clear strength in these areas is that most children have reasonably good access to educational services, schools can be used as an important gateway to address some of the dire economic and emotional needs of children affected by HIVrelated illness in the family.

\section{Acknowledgements}

The first author was working for the Human Sciences Research Council at the time of the research being done. The larger project, of which this study is a part, was funded by the W.K. Kellogg Foundation. The Nelson Mandela Children's Fund assisted in the running of the broader project.

\section{Competing interests}

The authors declare that they have no financial or personal relationship(s) which may have inappropriately influenced them in writing this paper.

\section{Authors' contributions}

The paper was primarily written and the analysis done by the first author, D.S. (Stellenbosch University), with direct input from C.S. (University of Houston). S.J. and L.S. (Human Sciences Research Council) and S.M. (University of the Western Cape) contributed to the design of the study and the research instruments and played a key role in the early analysis of the data. L.S. was also the project leader for the larger study. 


\section{References}

Bachman, M. \& Booysen, F., 2006, 'Economic causes and effects of AIDS in South African households', AIDS, 20(14), 1861-1867. http://dx.doi.org/10.1097/01. aids.0000244205.03382.84 [password protected], PMid:16954727

Barnett, T. \& Whiteside, A., 2002, AIDS in the twenty-first century: Disease and globalization, 2nd edn., Palgrave MacMillan, Pietermaritzburg, South Africa. http:// dx.doi.org/10.1057/9780230599208

Berry, L., \& Guthrie, T., 2003, The situation of children in South Africa, Children's Institute, University of Cape Town, Cape Town.

City Council of Klerksdorp, 2003, 2002/3 Annual report: Klerksdorp, City Council of Klerksdorp, Klerksdorp.

Cluver, L. \& Gardner, F., 2007, 'Risk and protective factors for psychological wellbeing of children orphaned by AIDS in Cape Town: A qualitative study of children and caregivers' perspectives', AIDS Care, 19(3), 318-325. http://dx.doi.org/10. 1080/09540120600986578, PMid:17453564

Department of Health (DoH), 2008, The National HIV and Syphilis Prevalence survey in South Africa - 2008, Department of Health, Pretoria.

Department of Health (DoH), 2009, The National HIV and Syphilis Prevalence survey in South Africa - 2007. Department of Health, Pretoria.

Desmond, C. \& Gow, J., 2001, 'The current and future impact of the HIV/AIDS epidemic on South Africa's children', in G.A. Cornia (ed.), AIDS, public policy and child wellbeing, pp. 57-73, Unicef, New York.

Donahue, J., 2005, 'Strengthening households and communities: The key to reducing the economic impacts of HIV/AIDs on children and families', in G. Foster, C. Levine \& J. Williamson (eds), A generation at-risk. The global impact of HIV/AIDS on orphans and vulnerable children, pp. 37-65, Cambridge University Press, New York.
Hill, S. \& Smith, C., 2003, Child well-being and poverty indicators in South Africa: Creating the real picture, IDASA, Cape Town.

Johnson, L. \& Dorrington, R., 2001, The impact of AIDS on orphanhood in South Africa: A quantitative analysis, Centre for Actuarial Research (CARE), Cape Town.

Shisana, O., Rehle, T., Simbayi, L., Parker, W., Zuma, K., Bhana, A., et al. , 2005, South African national prevalence, HIV incidence, behaviour and communication survey, 2005, HSRC Press, Cape Town.

Shisana, O., Rehle, T., Simbayi, L.C., Zuma, K., Jooste, S., Pillay-van-Wyk, V., et al. , 2009 South African national HIV prevalence, incidence, behaviour and communication survey 2008: A turning tide among teenagers?, HSRC Press, Cape Town.

Skinner, D. \& Davids, A. (eds.), 2006, Multiple vulnerabilities: Qualitative data for the study of orphans and vulnerable children in South Africa, HSRC Press, Cape Town.

Skinner, D., Tsheko, N., Mtero-Munyati, S., Segwabe, M., Chibatamoto, P., Mfecane, S., et al., 2006, 'Towards a Definition of Orphaned and Vulnerable Children, AIDS and Behaviour, 10(6), 619-627. http://dx.doi.org/10.1007/s10461-006-9086-6, PMid:16639543

Smart, R.A., 2003, Policies for orphans and vulnerable children: A framework for moving ahead, Policy project, USAID, Washington.

Statistics South Africa, 2001, Census 2001, Statistics South Africa, Pretoria.

UNAIDS, 2004, 2004 Report on the global AIDS epidemic, UNAIDS, Geneva.

UNICEF, 2003, Africa's orphaned generations, UNICEF, New York.

Xhariep Integrated Development Plan (Revised) 2003, unpublished.

Whiteside, A., 2000, 'The real challenges: The orphan generation and employment creation', AIDS Analysis Africa, 10(4), 14-15. PMid:12349436

Wild, L., Flisher, A., Laas, S. \& Robertson, B., 2005, 'The psychosocial adjustment of adolescents orphaned in the context of HIV/AIDS', unpublished manuscript, Department of Psychology, University of Cape Town, South Africa. 